\title{
Testes and body weight alteration related cardamom extract administration in mice
}

\author{
Tyagita Hartady ${ }^{1, *}$, Arvia Nisrina Praditha $^{1}$, Nabila Ayu Faza ${ }^{1}$, Rini Widyastuti ${ }^{1,2}$ \\ ${ }^{1}$ Study Program of Veterinary Medicine, Depart ment of Bio medical Science, Faculty of Medicine, \\ Padjadjaran University \\ ${ }^{2}$ Laboratory of Animal Reproduction and Artificial Insemination, Department of Animal Production, \\ Faculty of Animal Husbandry, Padjadjaran University
}

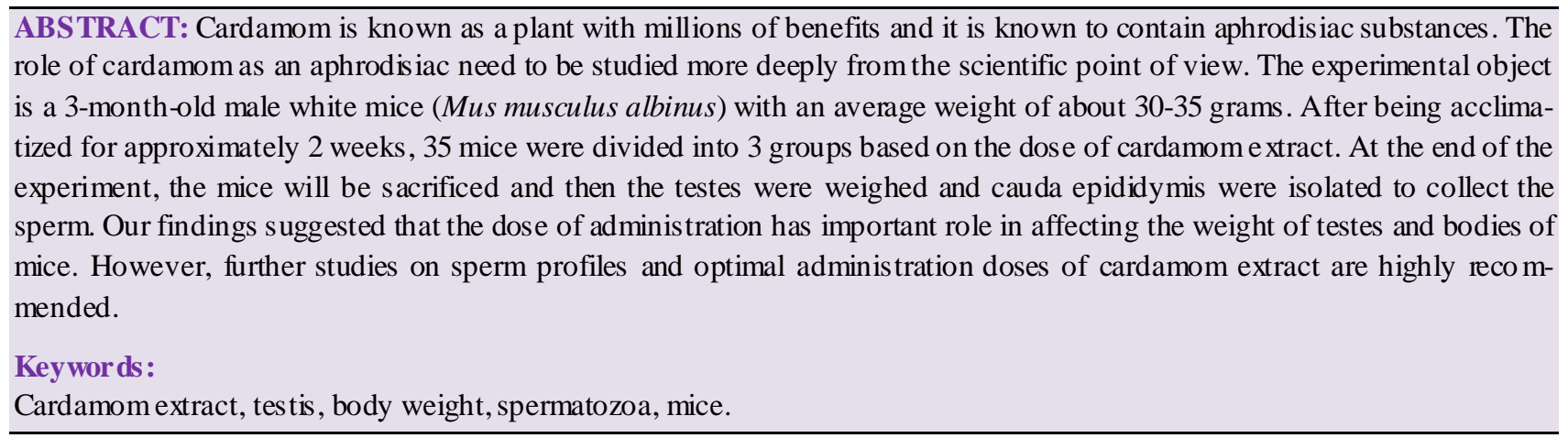

\section{- INTRODUCTION}

Cardamom is included in Zingiberales, family Zingiberaceae (Ginger tribe) genus (Amomum) and species Amomum compactum Sol ex. Maton (Hartono, 1996). This plant can grow up to 2 meters high, with mizomes that grow underground. The shape is round, $1-2 \mathrm{~cm}$ wide, yellowish white, covered with reddish brown hairless scales (Wolf \& Hartutiningsih, 1999). Cardamom is known to contain aphrodisiac substances such as cineole, camphor, borneol and geraniol. Cineole contained in cardamom is a type of 1.8-cineole and is known to be the most element contained in cardamom seeds. In essential cardamom oil reviewed by Bandhari et al. (2013), containing at least $73.27 \%$ of 1,8 -cineole. Cineole is known to increase blood flow and relax muscles (Klein, 2018). In addition, cardamom is proven to contain zinc and minerals and functions as cellular building element in the reproductive organs. Cardamom also contains androgenic components like borneol, cineole, citronellol and geraniol which can overcome erectile problems and decreased sexual arousal (Dukes, 1993).

The role of cardamom as an aphrodisiac need to be studied deeper from the scientific point of view. The limited available information was the reason for us to conduct this research. Even though cardamom contains many chemical elements, but it is not yet known what compounds have more or dominant effects on the system central nerve so that affect the male reproductive organs.

\section{- MATERIALS AND METHODS}

The experimental object was a 3-month-old male white mice (Mus musculus albinus) with an average weight of about 30-35 g. After being acclimatized for approximately 2 weeks, 27 mice were divided into 3 groups based on the dose of cardamom extract i.e. Control $(n=9)$, Group $1(n=9)$ : mice given cardamom extract for 30 days at a dose of 3.9 $\mathrm{mg} / 30 \mathrm{gBW}$, and Group 2 ( $\mathrm{n}=9)$ : mice given cardamom extract for 30 days at a dose of $4.5 \mathrm{mg} / 30 \mathrm{mgBW}$. The mice were given feed and drink ad libitum. At the end of the experiment (30th day), the mice sacrificed and then the testes were weighed and cauda epididymis was isolated to collect the sperm. The suspension of spermatozoa from cauda epididymis will be used for observations of sperm motility and their number as carried out by Partodihardjo (1992). The data will be statistically analyzed using One-way ANOVA.

\section{RESULTS}

As informed before, the treatment was held for about a month and the results showed any differences among groups based on the variable observed. The both side testicular weight between negative control group and the group 1 , showed the same average weight, where the right and left

Diteri ma: 07-12-201 8 | Dire visi: 29-1 2-2018 | Dis et ujui : 07 -01-2019

(C) 2019 CC-BY-SA. Ini adalah artikel Open Access yang didistribusikan berdasarkan ketentuan dari Creative Commons Attribution ShareAlike 4.0 International License (https://creativecommons.org/licenses/by-sa/4.0/). 
testis average of Group 1 were $0.12 \pm 0.01$ grams each and the right and left testis average of Control Group were $0.09 \pm 0.00$ and $0.08 \pm 0.01$. While the group 2 showed significance difference with the previous groups, $0.13 \pm 0.00$ and $0.12 \pm 0.00$ grams for the right and left testicular. The comparison of the testicular weight differences is well described in Fig. 1.

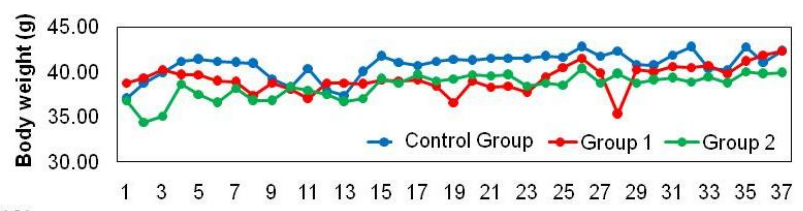

(A) days

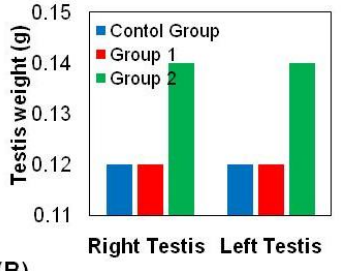

(B)

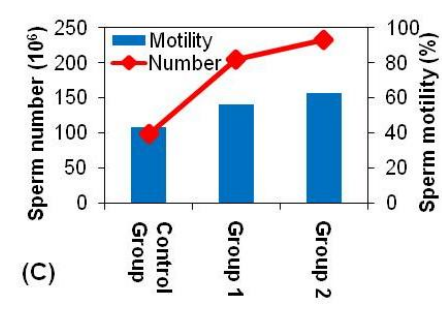

Figure 1 (A) body weight, (B) testis weight, and (C) number and motility of mice spermatozoa among groups.

Other parameter from our findings is the serial body weight of mice from all groups did not change significantly in weight gain. In the Control Group, when mice experienced an increase in body weight of approximately 1 gram, then a period of 6 days later, their body weight will decline again. The average body weight of Control Group was $40.80 \pm 2.43$ grams. Not much different from the Control Group, mice in Group 1 also experienced increases and decreases in body weight in a relatively shorter time. In approximately 4 days after experiencing a 1-2 gram increased, the body weight of mice will decrease by 1.5-2.0 grams. Data obtained from Group 2 tends to stagnate day by day with the average body weight of mice $38.42 \pm 2.65$ grams, which is the smallest average compared to the other two groups.

\section{- DISCUSSION}

It has been stated that three of several parameters of sperm profile has strongest correlation with testicular volume, they are sperm density, total sperm count per ejaculate, and percentage of motile sperm (Arai et al., 1998). Testis size is closely related to the sperm and testosterone contained (Takihara et al., 1987). The more the testes volume, the more sperm and testosterone produced. Group 2 received the highest dose of administration, $4.5 \mathrm{mg} / 30 \mathrm{mgBW}$. Surprisingly, the average of total testis weight was significantly become the highest among other groups, 0.14 grams for both side testes. The correlation also found in the other two groups where Group 1 was in the next decreasing order with lower testicular weight in average ( 0.12 grams for both side). The dose administration of cardamom extract was 3.9 $\mathrm{mg} / 30 \mathrm{mgBW}$, lower than the second treated group. The negative Control Group has never administered with any cardamom extract. Its variable was the same with the Group
1 which accepted the smallest dose of cardamom extract were 0.12 grams for the both-side testicular weight.

Cardamom is declared as a safe herb for the body. Some non-scientific based information states that cardamom can be healthy for the body and can accelerate fat buming so that it can reduce body weight without side effects. This is because the melatonin contained in it can increase the burning of fat in the body. Melatonin increases the stimulation of important fat cells (beige fat) and helps in buming calories in white adipose tissue (Jiménez-Aranda et al., 2013).

\section{- CONCLUSION}

The highest dose of administration in our study has proven the effect of cardamom in raising the testis and body weight in mice. Further study about the sperm profile and optimum administration dos age are highly recommended.

\section{- AUTHOR INFORMATION}

\section{Author Information}

*TH: tyagita.hartady@gmail.com Study Program of Veterinary Medicine, Department of Biomedical Science, Faculty of Medicine, Padjadjaran University Jl. Raya Bandung Sumedan g KM 21, Jatinangor 45363

\section{- ACKNOWLEDGEMENT}

The study was supported by Padjadjaran University through Hibah Intemal Unpad Competitive Grant.

\section{- REFERENCES}

Arai T, Kitahara S, Horiuchi S, Sumi S, Yoshida K. 1998. Relationship of testicular volume to semen profiles and serum hormone concentrations in infertile Japanese males. International Journal of Fertility and Women's Medicine, 43(1): 40-47.

Bandhari AK, Bisht VK, Negi JS, Baunthiyal M. 2013. 1, 8Cineole: A predominant component in the essential oil of large cardamom (Amomum subulatum Roxb.). Journal of Medicinal Plants Research. 7(26): 1957-1960.

Dukes JA. 1993. CRC Han dbook of Alternative Cash Crops. Florida: CRC Press.p240-241.

Hartono S. 1996. Tumbuhan Monokotil. Cetakan I. Jakarta: Penerbit Swadaya. p 77.

Jiménez-Aranda A, Fernández-Vázquez G, Campos D, Tassi M, Velasco-Perez L, Tan DX, Reiter RJ, Agil A. 2013. Melatonin induces browning of inguinal white adipose tissue in Zucker diabetic fatty rats. Journal of pineal research. 55(4):416-23.

Klein L. 2018. 22 Aphrodisiac Foods: Boost Your Sex Drive, Deliciously! Let's Get it On...in the Kitchen!! http://www.or ganicauthority.com/mojo-foods/11-foods-that-getyour-sex-drive-going-naturally.html. (18 Januari 2018).

Partodiharjo S. 1992. Ilmu Reproduksi Hewan. Mutiara Sumber Widya. Jakarta

Takihara H, Cosentino MJ, Sakatoku J, Cockett ATK. 1987. Sign ificance of Testicular Size Measurement in Andrology: II. Correlation of Testicular Size with Testicular Function. The Journal of Urology, 137(3):416-419.

Wolf XY, Hartutiningsih. 1999. Amomum compactum Soland. ex Maton, dalam C.C. de Guzman and J.S. Siemonsma (eds.). Plant Resources of South-East Asia 13: Spices. PROSEA. Bogor. p6871 . 